\title{
32. BOREHOLE TELEVIEWER DATA ANALYSIS FROM THE NEW HEBRIDES ISLAND ARC: THE STATE OF STRESS AT HOLES 829A AND 831B ${ }^{1}$
}

\author{
Anton Krammer, ${ }^{2}$ Stefan Menger, ${ }^{3}$ Thierry Chabernaud, ${ }^{4}$ and Karl Fuchs ${ }^{2}$
}

\begin{abstract}
Analysis of borehole televiewer and Formation MicroScanner data from Ocean Drilling Program (ODP) Holes 829A and 831B, located in the Vanuatu subduction zone, reveals that both boreholes are elongated. However, borehole televiewer data from neither borehole show the classical form of borehole breakouts (enlargements on opposite sides in an otherwise circular wellbore); rather, the data indicate smooth, varying borehole surfaces. The orientation of the borehole elongation in Hole $829 \mathrm{~A}\left(123^{\circ} \pm 16^{\circ}\right)$ parallels topography and structural lineaments. In Hole $831 \mathrm{~B}$ the orientation of elongation $\left(148^{\circ} \pm 19^{\circ}\right)$ is roughly perpendicular to the direction of plate convergence $\left(76^{\circ}\right)$.

Focal mechanism solutions show that in the area of investigation the overriding plate is characterized by an east-northeastwest-southwest directed compressional stress regime. This indicates, that the orientation of the minimum horizontal stress direction, where compressive shear failure occurs, is parallel to the strike of the Australia/Pacific Plate boundary. Calculation of finite element modelling also show that high compressive stresses are assumed in accretionary wedges (Bott et al., 1989).

The correlation of the orientation of the elongations in both wellbores with the local and regional stress field implies that the orientation of borehole elongation results from the present day stress field. Orientation of borehole elongation of Hole 831B strikes parallel to the Australia/Pacific Plate boundary indicating that it is consistent with the stress field deduced from earthquake focal mechanisms. However, orientation of borehole elongation of Hole $829 \mathrm{~A}$ is affected by the local rather than the regional stress field. Observed local tectonics and topography superimpose the regional stress field at this drill site and lead to a $43^{\circ}$ northward rotation of the maximum horizontal stress field.

Additionally, the existence of a smooth borehole surface rather than borehole breakouts implies that despite the assumed high compressive stresses, additional processes, for example decoupling along thrust faults, must exist to reduce these stresses.
\end{abstract}

\section{INTRODUCTION}

The compilation of global stress data provided by the World Stress Map Project (WSM; Zoback et al., 1989) is a fundamental source for the interpretation of lithospheric dynamics and the understanding of plate driving forces. The majority of stress data of the WSM database $(50 \%)$ is provided by focal plane solutions of continental earthquakes. Less than $6 \%$ of the stress data is of oceanic or continental shelf origin (B. Müller and M.L. Zoback, pers. comm., 1992). Borehole breakouts are reliable stress indicators in terms of determining horizontal stress directions (e.g., Zemanek et al., 1970; Bell and Gough, 1979; Zoback et al., 1985; Blümling and Schneider, 1986) in the upper crust. In combination with rock strength measurements this method can also provide constraints on stress magnitudes (Moos and Zoback, 1990). At present only a few in-situ stress observations are available for the oceanic crust (e.g., Newmark et al., 1984; Morin et al., 1990; Moos and Zoback, 1990; Castillo and O'Neill, 1992), and therefore, large areas of the oceanic crust are still unexplored in terms of stress. However, the Ocean Drilling Program (ODP) now offers the opportunity to close this gap by means of in-situ measurements in open boreholes.

During ODPLeg 134, which investigated the collision zone of the d'Entrecasteaux Zone (DEZ) with the New Hebrides Island Arc in the western Pacific Ocean (Fig. 1), borehole geometry data were collected using the borehole televiewer (BHTV). The BHTV is a borehole imaging tool that provides vertically and azimuthally high-resolution information about the shape of the borehole and the reflectivity of the borehole wall. Thus the collected data provide an opportunity to study

\footnotetext{
${ }^{1}$ Greene, H.G., Collot, J.-Y., Stokking, L.B., et al., 1994. Proc. ODP, Sci. Results, 134: College Station, TX (Ocean Drilling Program).

${ }^{2}$ Universităt Karlsruhe, Geophysikalisches Institut, Hertzstrasse 16, D-76187 Karlsruhe, Germany.

${ }^{3}$ Tondernstrasse 3, D-4400 Münster, Germany (formerly DMT, Institut für Angewandte Geophysik, Westhoffstrasse 17, D-4630 Bochum 1, Germany).

${ }^{4}$ Borehole Research Group, Lamont-Doherty Earth Observatory, Columbia University, Palisades, New York 10964, U.S.A.
}

the state of stress on both sides of the Australia/Pacific Plate boundary on either side of the collision zone of the aseismic DEZ and the New Hebrides Island Arc (Fig. 1).

\section{METHODS OF STRESS EVALUATION}

The use of stress-induced borehole breakouts as stress indicators is now a well established method of determining the horizontal stress direction in Earth's crust (e.g., Bell and Gough, 1979; Zoback et al., 1985; Blümling, 1986; Moos and Zoback, 1990; Mastin et al., 1991). Breakouts can be described as spalled regions on opposite sides of the borehole wall. They occur when the circumferential stress $\sigma_{\theta \theta}$ acting on the borehole wall exceeds the compressive strength (C) of the rock. An analytical description of the variation of the stresses acting at a circular hole was first given by Kirsch (1898).

In the simple case in which the wellbore is vertical, the vertical stress $S_{y}$ is a principal stress, and the rock at the wellbore behaves elastically, the effective stresses acting on the borehole wall can be described as follows:

$$
\begin{gathered}
\sigma_{\theta \theta}=S_{\text {Hmax }, \text { eff }}+S_{\text {hmin, eff }}-2\left(S_{\text {Hmax, eff }}-S_{\text {hmin, eff }}\right) \\
\times \cos 2 \theta-\Delta \mathrm{P}, \\
\sigma_{\text {rr }}=\Delta \mathrm{P}, \\
\sigma_{z z}=S v-2 v\left(S_{H \max , \text { eff }}-S_{\text {hmin, eff }}\right) \cos 2 \theta, \\
\tau_{z \theta}=\tau_{z \theta}=\tau_{r \theta}=0,
\end{gathered}
$$

with $S_{\mathrm{Hmax}, \text { eff }}$ being the effective maximum horizontal far field stress

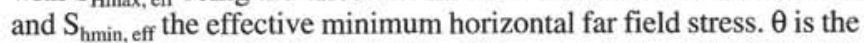
angle with respect to the direction of $\mathrm{S}_{\mathrm{H} \max }, v$ is the Poisson's ratio and $\triangle P$ describes the difference between the fluid pressure $\mathrm{p}_{\mathrm{o}}$ in the borehole and the pore pressure $\mathrm{p}_{\mathrm{p}}$ in the formation. 


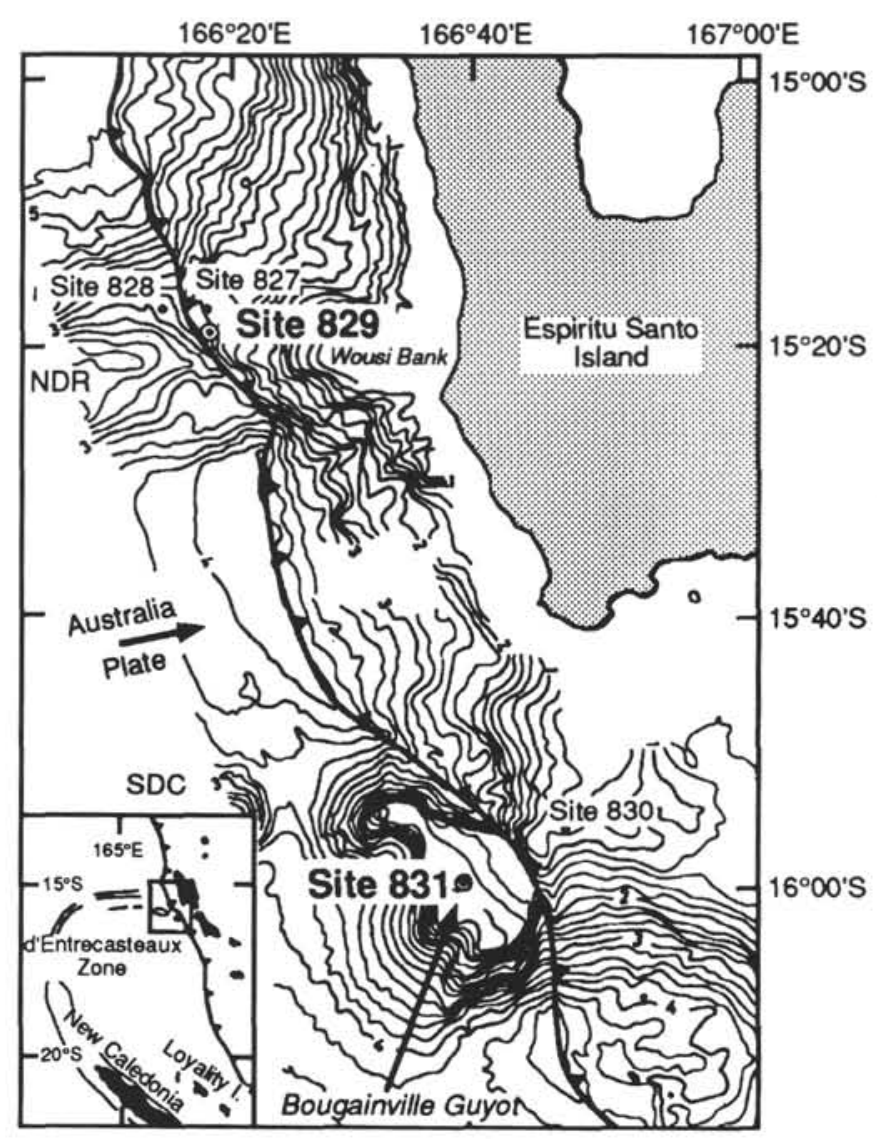

Figure 1. Location map of Leg 134 drill sites in the collision zone between the d'Entrecasteaux Zone and the Central New Hebrides Island Arc. Sites marked with bold letters indicate those sites where BHTV data is available. Bold line with teeth marks the Australia/Pacific Plate boundary, with teeth on upper plate. Bathymetric contours are in kilometers. NDR = North d'Entrecasteaux Ridge; SDC $=$ South d'Entrecasteaux Chain.

Breakouts will occur at the azimuth of $\mathrm{S}_{\mathrm{hmin}}\left(\theta=90^{\circ}, 270^{\circ}\right)$ if the compressive strength $\mathrm{C}$ of the rock is exceeded by the circumferential stress $\sigma_{\theta \theta}$ yielding for Equation 1:

$$
\begin{aligned}
\sigma_{\theta \theta}=S_{\mathrm{Hmax}, \text { eff }}+ & \mathrm{S}_{\text {hmin, eff }}-2\left(\mathrm{~S}_{\mathrm{Hmax}, \text { eff }}-\mathrm{S}_{\mathrm{hmin}, \text { eff }}\right) \\
& \times \cos 2 \theta-\Delta \mathrm{P} \geq \mathrm{C} .
\end{aligned}
$$

In the case that the tensile strength $T$ of the rock is exceeded, tensile failure of the wellbore will occur at the azimuth of $\mathrm{S}_{\mathrm{H} \max }\left(\theta=0^{\circ}\right.$, $\left.180^{\circ}\right)$ :

$$
\begin{aligned}
\sigma_{\theta \theta}=S_{\mathrm{Hmax}, \text { eff }}+ & \mathrm{S}_{\mathrm{hmin}, \text { eff }}-2\left(\mathrm{~S}_{\mathrm{Hmax}, \text { eff }}-\mathrm{S}_{\mathrm{hmin}, \text { eff }}\right) \\
& \times \cos 2 \theta-\Delta \mathrm{P} \leq-\mathrm{T}
\end{aligned}
$$

Figure 2 shows in principle the variation of the circumferential stress $\sigma_{\theta \theta}$ around a circular borehole. $\mathrm{C}$ and T represent compressive and tensile strengths of the rock. In those azimuth intervals where the compressive strength of the rock is exceeded breakouts occur (upper hatched area, Fig. 2), whereas when the tensile strength is exceeded tensile fractures occur (lower hatched area, Fig. 2).

In addition to the formulas described in Equations 1-4 temperature differences add additional stresses $\left(\sigma_{\theta \theta}[\Delta \mathrm{T}]\right)$ to the borehole wall (e.g., Ritchie and Sakakura, 1956; Timoshenko, 1959; Moos and Zoback, 1990; Morin et al., 1990). Therefore Equation 1 can be modified to reflect temperature as follows:

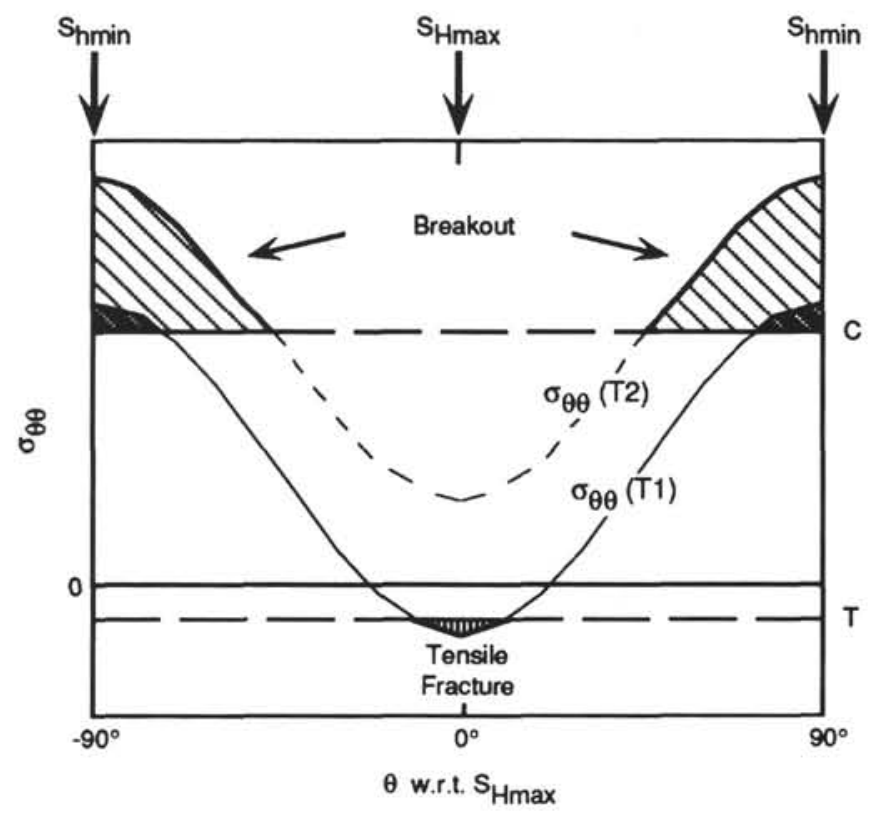

Figure 2. Variation of circumferential stress $\sigma_{\theta \theta}$ around a circular borehole wall (after Kirsch, 1898). C and T represent lines of the compressive and tensile strength of the rock. $\sigma_{\theta \theta}(\mathrm{T} 1)$ and $\sigma_{\theta \theta}(\mathrm{T} 2)$ indicate circumferential stresses for different temperatures $\mathrm{T} 1$ and $\mathrm{T} 2(\mathrm{~T} 1<\mathrm{T} 2)$ of the borehole fluid. Hatched areas show azimuths where compressive strength of the rock is exceeded by the circumferential stress $\sigma_{\theta \theta}(\mathrm{T} 1)$ (bold hatched area) and $\sigma_{\theta \theta}(\mathrm{T} 2)$ (hatched area), and therefore breakouts occur. Tensile fractures occur when the tensile strength is exceeded (lower hatched area).

$$
\begin{aligned}
\sigma_{\theta \theta}=\mathrm{S}_{\mathrm{Hmax}, \text { eff }} & +\mathrm{S}_{\mathrm{hmin}, \text { eff }}-2\left(\mathrm{~S}_{\mathrm{Hmax}, \text { eff }}-\mathrm{S}_{\mathrm{hmin}, \text { eff }}\right) \\
& \times \cos 2 \theta-\Delta \mathrm{P}+\sigma_{\theta \theta}(\Delta T),
\end{aligned}
$$

with $\sigma_{\theta \theta}(\Delta T)=\alpha \times \mathrm{E} \times \Delta T /(1-v)$. $\alpha$ describes the thermal coefficient of expansion, E the Young's modulus, and $\Delta T$ the temperature difference between the borehole fluid and the surrounding rock. Positive temperature differences (borehole fluid is warmer than the formation) will facilitate breakout occurrence while negative temperature differences will facilitate tensile cracks.

Only short depth intervals of the boreholes Hole 829A and Hole 831B show circular cross-sections; most of the depth intervals show a more elongated, elliptical cross-section (Fig. 3A). A more general form of Equation 1 is given by Muskhelishvili (1953) for an elliptical borehole under uniaxial stress. In case of an anisotropic stress field, the circumferential stress $\sigma_{\theta \theta}$ along the borehole wall is obtained by superposition of two orthogonally acting uniaxial stresses $\mathrm{S}_{\mathrm{H}}$ and $\mathrm{S}_{\mathrm{h}}$ (Eq. 1D), with $\mathrm{S}_{\mathrm{H}}$ in the direction of the $a$-axis and $\mathrm{S}_{\mathrm{h}}$ parallel to the $b$-axis of the ellipsoid (Fig. 3B).

$$
\begin{aligned}
& \sigma_{\theta \theta}=\left[\left\{\left(1-\mathrm{m}^{2}\right)\left(\mathrm{S}_{\mathrm{H}}+\mathrm{S}_{\mathrm{h}}\right)+2\left(\mathrm{~S}_{\mathrm{H}}-\mathrm{S}_{\mathrm{h}}\right)\right.\right. \\
& \left.\times(\mathrm{m}-\cos 2 \theta)\} /\left(1-2 \mathrm{~m} \cos 2 \theta+\mathrm{m}^{2}\right)\right]-\Delta \mathrm{P},
\end{aligned}
$$

where $\mathrm{m}=(\mathrm{a}-\mathrm{b}) /(\mathrm{a}+\mathrm{b})$ describes the ratio of the axes $(a, b)$ of the ellipsoid, and $\mathrm{S}_{\mathrm{H}}$ and $\mathrm{S}_{\mathrm{h}}$ the maximum and minimum effective horizontal far-field stresses. Equation ID reduces to Equation 1 for a circular borehole $(m=0)$. A comparison of circumferential stresses around the borehole wall in circular and elliptical boreholes in case of an anisotropic horizontal stress field is shown in Figure 3B. An upper theoretical limit for the ratio of $\mathrm{S}_{\mathrm{Hmax}} / \mathrm{S}_{\mathrm{hmin}}$ of 3:1 was assumed for the calculation of the circumferential stresses. A maximum ratio of about $1: 2$ for the axis of the ellipsoid $(m=-1 / 3)$ was observed in the BHTV data and was used as an upper limit for the calculations. 
The stress distributions for different ratios of $\mathrm{S}_{\mathrm{H} \max } / \mathrm{S}_{\mathrm{hmin}}$ and $\mathrm{a} / \mathrm{b}$ in Figure $3 \mathrm{~B}$ illustrate that under the above described conditions elliptical boreholes amplify stress concentration at $\theta=90^{\circ}$ and $180^{\circ}$, with respect to $\mathrm{S}_{\mathrm{H} \max }$ at the borehole wall. Reduction of the stress concentration occurs at $\theta=0^{\circ}$ and 270 , with respect to $S_{\mathrm{Hmax}}$. Therefore, under elliptical borehole conditions it is more likely that stress induced tensile fractures $\left(\theta=0^{\circ}, 180^{\circ}\right)$ or shear failure $\left(\theta=90^{\circ}, 270^{\circ}\right)$ will occur (Morin et al., 1989). However, neither tensile fractures nor breakouts were observed in the data of Hole 829A and Hole 831B from Leg 134, indicating that additional processes must be assumed, which reduced the applied stress.

\section{DESCRIPTION OF THE LOGGING TOOLS}

Borehole logging tools that are able to measure parameters relevant for stress analysis are the BHTV, the Formation MicroScanner (FMS), and the 4-arm caliper. The BHTV and FMS are described in the following sections.

\section{BHTV}

The BHTV is an ultrasonic logging device producing an oriented image of the borehole wall. The BHTV was described first in detail by Zemanek et al. (1969) and is used in borehole inspection for the detection of stress-induced wellbore breakouts, hydraulic fractures, and the analysis of structural features such as fractures and foliation. The BHTV employed on Leg 134 is a digital logging tool (slimhole BHTV, outer diameter $65 \mathrm{~mm}$ ) that is able to operate in temperatures up to $120^{\circ} \mathrm{C}$. The digital BHTV was used for the first time on an ODP leg with Leg 134. The complete digital BHTV system consists of a surface unit containing an IBM compatible PC and a power supply, and a downhole unit, which consists of an orientation unit, electronic unit, and an acoustic unit (Figs. 4A and B).

The surface unit (IBM PC, power supply) communicates with the downhole unit instruments (orientation, electronic, and acoustic unit) and incorporates the necessary software and hardware to run the BHTV and to store the collected data.

A3-component fluxgate magnetometer (orientation unit) provides orientation with respect to magnetic north. The electronic unit includes software and hardware for the downhole digitization and uphole transfer of the data.

The acoustic unit of the digital BHTV contains a fixed transducer and a rotating mirror (Fig. 4B). The transducer emits broadband ultrasonic pulses with a maximum of emitted energy at $1.2 \mathrm{MHz}$ (Menger, 1991) that are reflected by the mirror towards the borehole wall. The rotating mirror provides a complete azimuthal coverage of the borehole wall. Depending on the data transfer capacity and the size of the borehole, up to 512 pulses per revolution and 12 revolutions per second can be measured. The ODP configuration allows 128 samples per revolution and 6 revolutions per second. This gives a BHTV horizontal resolution of $3^{\circ}$, while the vertical resolution depends on the logging speed. In a given time window of $102 \mu$ s length, maximum amplitude and traveltime of the maximum amplitude of each reflected pulse from the borehole wall are automatically selected. From the recorded depth, amplitude and travel time data, an amplitude-depth and traveltimedepth image of the borehole wall can be produced (Fig. 5).

\section{FMS}

The FMS is an extended version of the 4-arm dipmeter, which is a standard logging tool in the exploration industry and has been available for ODP since Leg 126 (Pezard, 1987). It was described in detail by Ekstrom et al. (1987) and consists of two crossed orthogonal arms with a pad at each end of the arms. Two rows of eight buttons are embedded on each pad. As the FMS is pulled out of the well it rotates due to torsion on the cable. The four pads are hydraulically pressed against the wall while a current is emitted and recorded. A new measurement is recorded every $2.5 \mathrm{~mm}$, which provides a very
Hole 829A

Hole 831B

A

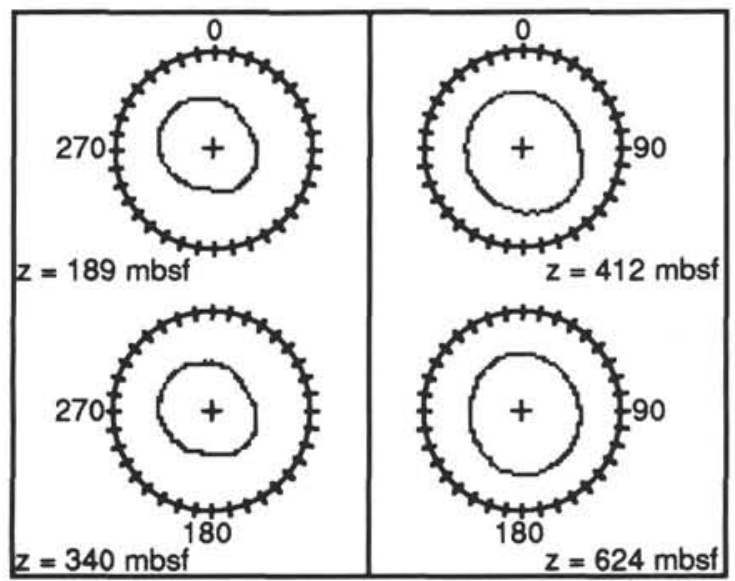

B

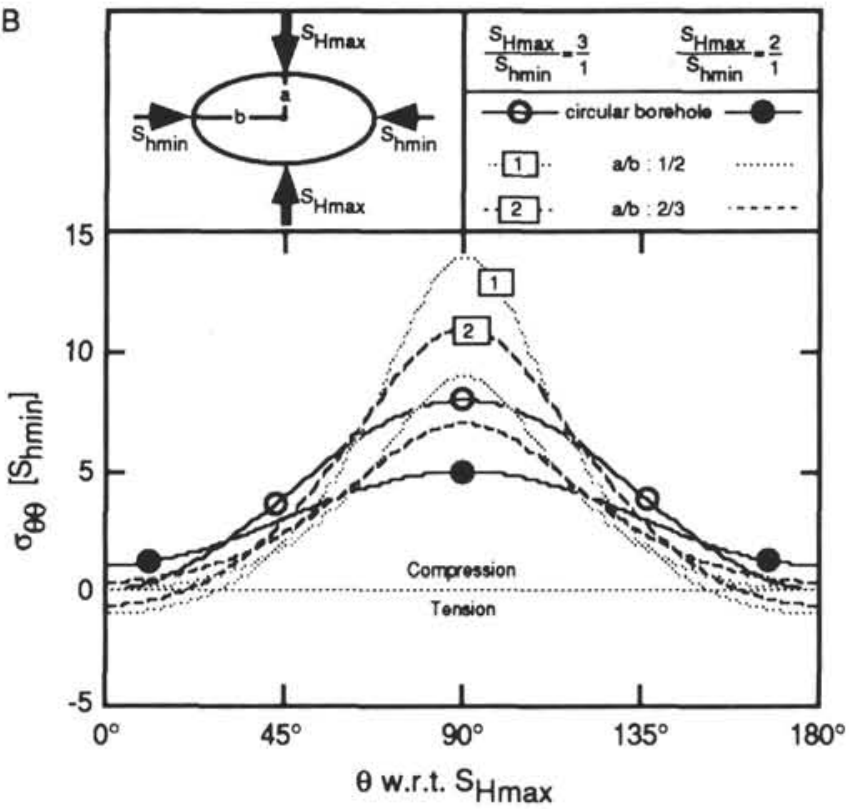

Figure 3. A. Borehole cross-sections of ODP holes 829A (left) and 831B (right) from different depth levels. All cross-sections are oriented with respect to magnetic north and indicate the highly deformed borehole with borehole elongations to the SE (left) and SE to SSE (right). Cross-sections of Hole 829A are marked by key seat-like elongations. B. Comparison of circumferential stress $\sigma_{\theta \theta}$ around a circular and elliptical borehole wall. Top: sketch of the nomenclature used. Bottom: variation of the circumferential stresses around a circular and elliptical borehole wall at a hypothetical $\mathrm{S}_{\mathrm{H} \max } / \mathrm{S}_{\mathrm{hmin}}$-ratio of 3:1 and $2: 1$ and ratios of the borehole axis of 1:2 and 2:3.

high resolution image of the electrical conductivity within a few centimeters of the borehole wall. The FMS is an excellent logging tool for detecting vertical fractures in the borehole wall when those fractures are filled with a conductive material such as the wellbore fluid. Therefore vertical fractures express a high conductivity zone in comparison to the surrounding rock. Due to the restricted size of the pads only a limited region of the borehole wall is covered. For ideal conditions in ODP wells, for example when the borehole diameter equals bit size (e.g., 9-7/8 in.), only a maximum coverage of $25 \%$ of the borehole wall is possible.

\section{DATA ANALYSIS}

During Leg 134 Holes 829A and 831B, both in close vicinity to the Australia/Pacific Plate boundary, were logged with the BHTV and 
A

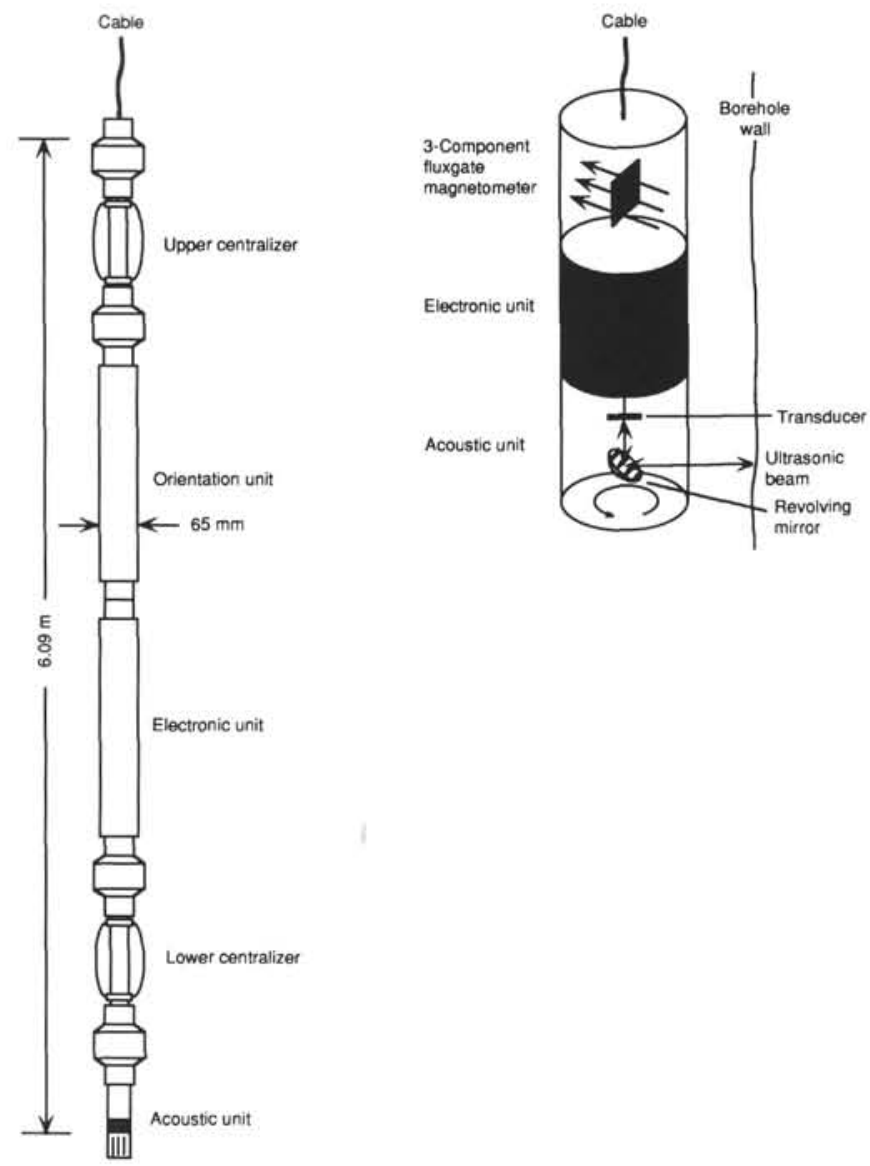

Figure 4. Digital borehole televiewer (BHTV). General tool setup of the digital BHTV and schematic of the digital BHTV.

FMS. All of this data was first corrected for the magnetic declination and then analyzed for stress indicators. BHTV data was studied in terms of breakouts and vertical fractures, while FMS data was analyzed in terms of vertical fractures only. Borehole geometry data from the FMS (caliper 1, caliper 2, hole deviation, hole azimuth, pad 1 azimuth) was investigated for borehole breakouts using criteria described by Plumb and Hickman (1985) in their original work about breakout detection with dipmeter and BHTV in sedimentary rocks. Additionally, structural features, displayed as sinusoids in the amplitude and/or radius image (Fig. 5) of the BHTV were analyzed with respect to dip direction and dip. A detailed description of the analysis techniques used for the BHTV data is given by Barton et al. (1991).

\section{Hole 829A}

Hole 829A was drilled into the accretionary wedge on the eastern side of the Australia/Pacific Plate boundary (Fig. 1). More than 16 different lithostratigraphic units were intersected before the final depth of 590 meters below sea floor (mbsf) was reached. Two BHTV logs were recorded, the first from 429 to $155 \mathrm{mbsf}$ and a repeat run from 374 to $166 \mathrm{mbsf}$. During the first run the vertical logging speed was $100 \mathrm{~m} / \mathrm{h}$. The bow springs of the centralizer were unusually stiff, thus jerking the tool (logging the same depth interval for several revolutions accompanied by a sudden upwards movement of the tool because of the release of the cable tension). To avoid jerking, the tool was run at $300 \mathrm{~m} / \mathrm{h}$ during the second run. This increased data quality considerably but at the expense of vertical resolution. Two FMS runs were also recorded from 48 to $467 \mathrm{mbsf}$ and 156 to $471 \mathrm{mbsf}$. Caliper and orientation data of this hole are displayed in Figure 6A with the orientation of borehole elongations derived from BHTV data.

It is obvious from this data that with the exception of the lower (380-470 mbsf) and uppermost logged part (70-170 mbsf) of the borehole the FMS tool was hardly rotating, while the calipers showed a consistent, approximately 2 in. difference between the long and short axes of the hole (Fig. 6A). This pronounced eccentricity in these parts of the hole (170-380 mbsf) prevented the FMS tool from rotating. Within this depth interval the deviation of the borehole reduced from $5^{\circ}$ to $3^{\circ}$. Applying the criteria of Plumb and Hickman (1985) to the data this would have resulted in interpreting this depth interval as a breakout section. Analysis of BHTV data showed that the orientation of elongation $\left(123^{\circ} \pm 16^{\circ}\right)$ correlates with the orientation of the pad 1 azimuth (P1 azimuth) of the FMS (Fig. 6A). However, cross-sections of the BHTV data, as they give a complete coverage of the borehole wall and therefore are most reliable, clearly show that the borehole surface is smooth and that elongations of the borehole (Fig. $3 \mathrm{~A}$ ) do not show the typical patterns of stress-induced breakouts (sharp cut-ins into the borehole wall).

Analysis of the orientation of intersecting structures (fractures) indicated steeply dipping fractures with a preferred orientation of the dip directions toward $80^{\circ}$ (Fig. 7A). This is a $43^{\circ}$ rotation with respect to the orientation of elongation and agrees with analysis of structural data from FMS data that indicates in the logged interval (190-460 mbsf) most of the structures dip northeast to southwest (Collot, Greene, Stokking, et al., 1992). Whereas, it is not possible from these dipmeter data to distinguish between the dips of bedding planes or fault planes.

\section{Hole 831B}

Hole 831B is situated on the summit of the Bougainville Guyot (Fig. 1) on the western side of the Australia/Pacific Plate boundary. More than $700 \mathrm{~m}$ of carbonates and $120 \mathrm{~m}$ of andesitic breccia, representing the weathered surface of the volcanic rocks, were drilled in the hole (total depth: $852 \mathrm{mbsf}$ ). The open section of the borehole reaching from 740 to $95 \mathrm{mbsf}$ (end of drillpipe) was nearly completely logged twice with the BHTV at $300 \mathrm{~m} / \mathrm{h}$. FMS data in Hole $831 \mathrm{~B}$ were collected from 762 to 83 mbsf and 763 to 552 mbsf. Dipmeter data from the FMS tool are presented in Figure 6B. They show that there is a general increase in the borehole diameter of 2 to 4 in., indicating these intervals as washouts according to Plumb and Hickman (1985). In addition, with the exception of a few depth sections, a constant rotation over nearly the complete logged depth interval (Fig. 6B) can be observed in the data. This can be related to a smooth surface of the borehole wall, which was observed all over the wellbore, and less eccentricity. Within the lowermost $15 \mathrm{~m}$ of the logged depth intervals, where cross-sections also show a smooth wellbore surface, borehole elongation deduced from BHTV and from FMS caliper data show a borehole elongation of $200^{\circ}$. This is $50^{\circ}$ off from the overall orientation of elongation of $148^{\circ} \pm 19^{\circ}$ (Fig. 3A), determined from BHTV cross-sections. A preferred orientation of the intermediate to steeply dipping structures was not detected (Fig. 7B).

The examination of the BHTV data with respect to borehole breakouts clearly showed that breakouts occurred neither in Hole 829A nor in Hole 831B. The advantage of using BHTV data rather than caliper data can be seen in the two data sets of the depth interval from 170-380 mbsf of Hole 829A. Caliper data of this borehole (Fig. 6A) would have been misinterpreted as stress induced breakouts using the criteria of Plumb and Hickman (1985), even if the effects of deviation on breakouts would have been incorporated (Mastin, 1988). However, BHTV data clearly show, that there is no breakout in the above mentioned depth section, despite a pronounced borehole elongation. Symmetrical vertical fractures, which could be related to stress- or drillinginduced effects, were not observed either in the BHTV or FMS data set. However, both boreholes showed an extremely well-developed eccentricity of the borehole shape (Fig. 3A). Throughout the boreholes the direction of eccentricity (azimuth of the long axis of the borehole) 

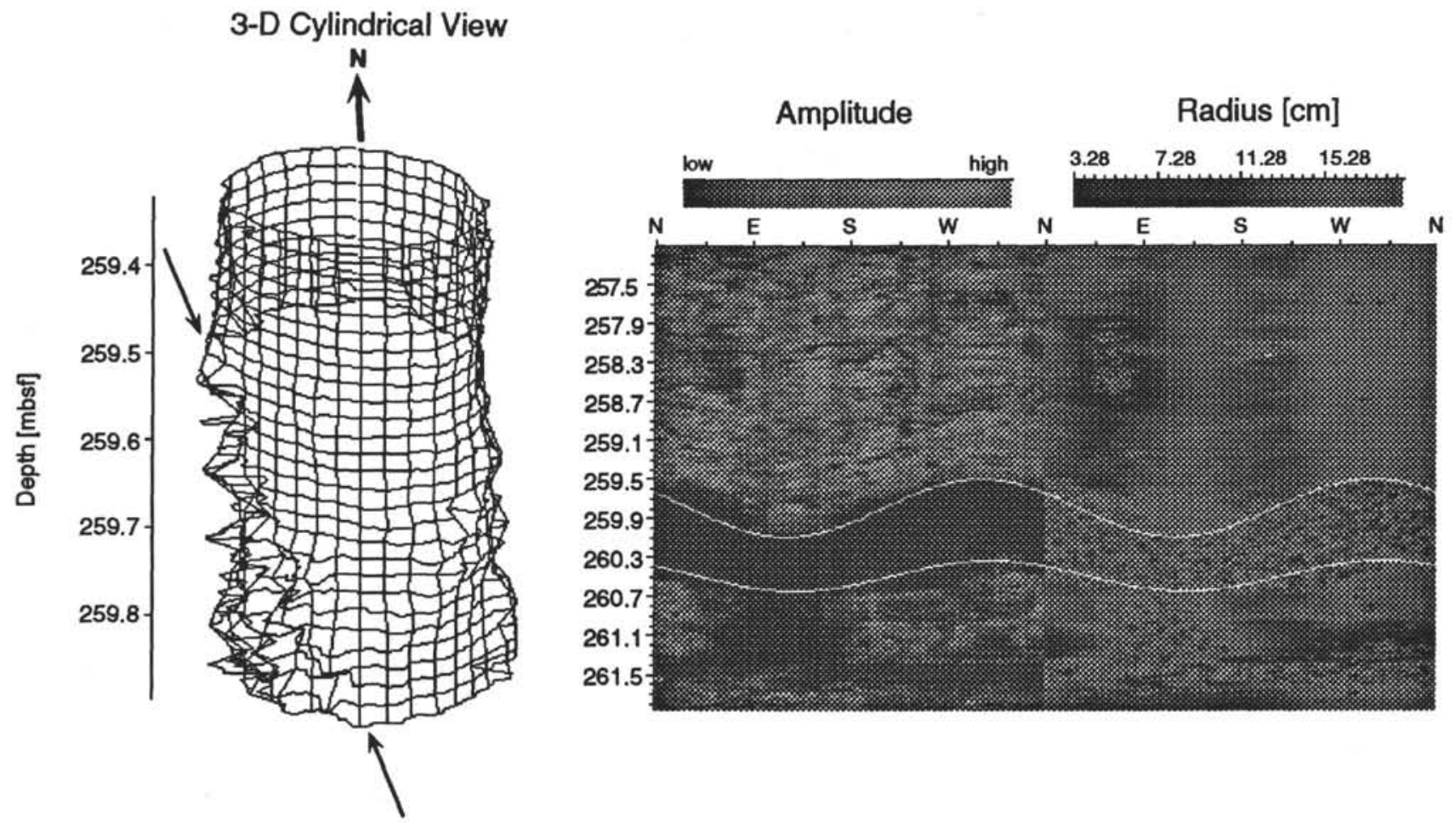

Figure 5. Borehole televiewer images from Hole 829A. Left: 3-dimensional data projection. Light arrows mark the change from a smooth to a rough borehole surface, which indicates an intersecting structure, also shown between the white sinusoids of the amplitude and radius image. Right: Unwrapped borehole televiewer amplitude and radius image. Sinusoids mark intersecting structure with a dip direction of $107^{\circ} \mathrm{E}$ and a dip of $61^{\circ}$.

was determined from BHTV data and compared with borehole geometry data obtained from the FMS (Figs. 6A and 6B).

BHTV data analysis of the orientation of the elongated borehole axis in Hole $829 \mathrm{~A}$ and Hole $831 \mathrm{~B}$ show only slight variations with depth. The calculation of the orientation of the elongations from BHTV data, using circular statistics (Mardia, 1972), gives the following results:

Hole 829A: Orientation of elongation $=123^{\circ} \pm 16^{\circ}$

Hole 831B: Orientation of elongation $=148^{\circ} \pm 19^{\circ}$

Figures $8 \mathrm{~A}$ and $8 \mathrm{~B}$ illustrate these orientations on detailed bathymetric maps of the location sites. The orientations show that they correlate well with topography in Hole $829 \mathrm{~A}$ and with the strike of the plate boundary in Hole 831B.

\section{DISCUSSION}

\section{Information from Modelling and Tectonic Forces}

A major objective of Leg 134 was the study of the ridge/arc collision-subduction processes active within the DEZ-New Hebrides Island Arc collision zone. Subduction zones include regions of highcompressive stress with a complex interaction of plate driving forces (Forsyth \& Uyeda, 1975). Chapple (1979) proposed large horizontal compression in the accretionary wedge above the basal décollement. Breakouts were expected to occur in depths reached by drilling into the accretionary wedge, in a similar manner as found from finite element modelling of the state of stress in the overriding and subducting plate at subduction zones (Bott et al., 1989), stress magnitudes on the order of 100-150 MPa were calculated in the overriding plate. For the New Hebrides trench region of the Australia Plate a tensile stress on the order of $150 \mathrm{MPa}$ was calculated from Cloetingh and Wortel (1986). Thus, the numerical models predict a high horizontal stress gradient across the plate boundary with the dominance of thrust faulting in the overriding plate and normal faulting in the subducting plate.
Figures 9A and 9B show the distribution of seismicity in the Vanuatu region of the Central New Hebrides Island Arc derived from centroid moment tensor (CMT) solutions for the years 1977-1990 (Dziewonski, Franzen, Woodhouse, 1983a, b; Dziewonski, Friedmann, et al., 1983; Dziewonski, Franzen, Woodhouse, 1984a-f, 1985, 1986a-c; Dziewonski, Ekström, et al., 1987a-f; Dziewonski, Ekström, Woodhouse, Zwart, 1987, 1988a-c; Dziewonski, Ekström, Franzen, Woodhouse, 1988a-c; Dziewonski, Ekström, Woodhouse, Zwart, 1989a-e, 1990). Stress orientations have been derived from $P$, $\mathrm{T}$, and $\mathrm{B}$ axes of those earthquakes. These CMT solutions show a prevailing east-northeast-west-southwest directed compression, which is normal to the plate boundary (Fig. 9A). Looking at the data in more detail, it appears that normal faulting occurs close to and west of the plate boundary simultaneously with reverse faulting for depths less than $50 \mathrm{~km}$ (Fig. 9B). These normal faulting events occur on the downgoing slab and therefore can be associated with bending of the downgoing slab. However, thrust faulting as well as strike slip faulting is dominant both for depths greater than $100 \mathrm{~km}$ and for shallow earthquakes $0.5^{\circ}$ east of the plate boundary.

\section{Conditions of Breakout Occurrence and Magnitude Estimation}

For the estimation of the stress magnitudes and the probability of breakout occurrence at Holes 829A and 831B a simple model can be used (Moos and Zoback, 1990). For this model we make the following assumptions:

1. The vertical stress $\left(\mathrm{S}_{\mathrm{v}}\right)$ is a principal stress.

2. The rock is assumed to behave like an isotropic elastic material.

3. Pore pressure is assumed to be hydrostatic $P_{p}=\rho_{w} \times g \times z$.

4. For these calculations the frictional coefficient $\mu$ in the preferentially oriented planes of weakness is assumed to be 0.8 (Byerlee, 1978) as an upper limit for tectonic stress. 
A

BHTV

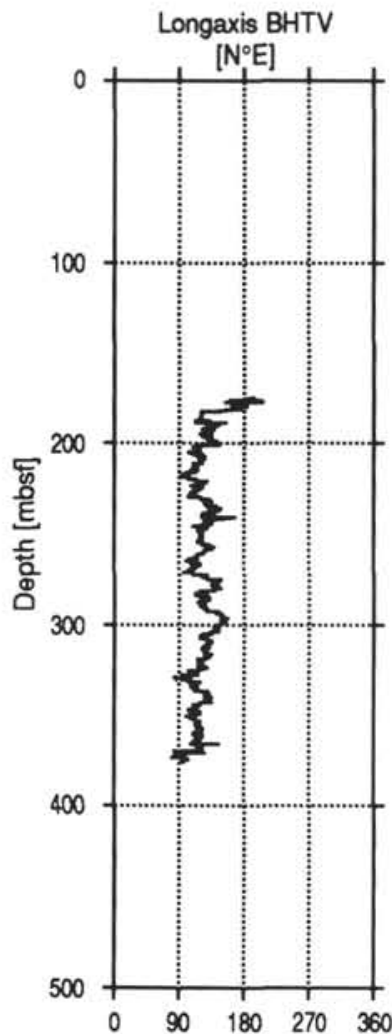

B

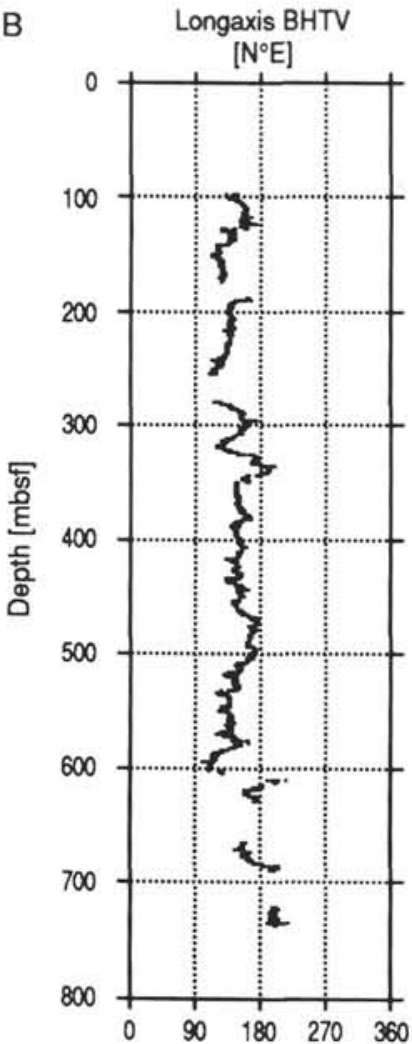

FMS
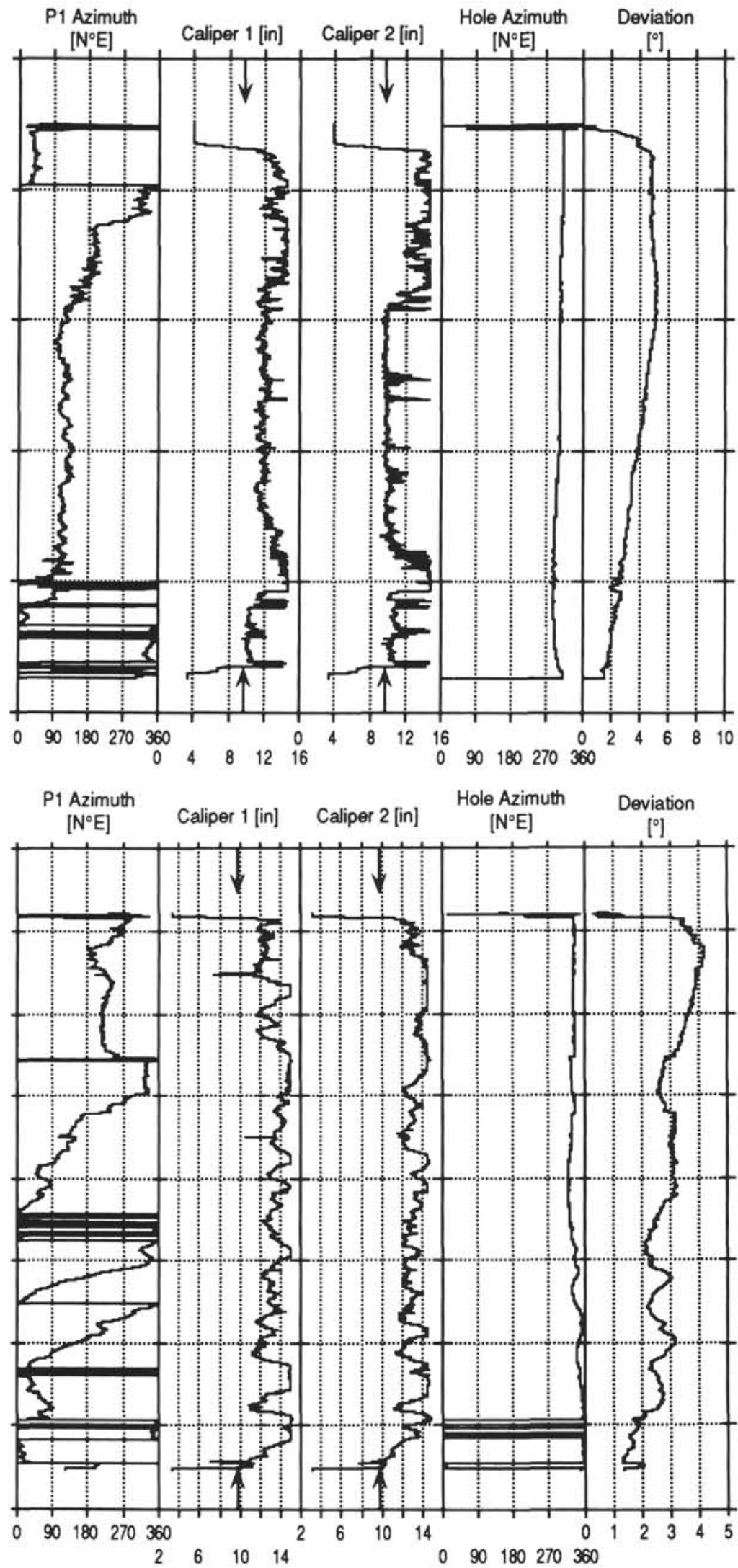

Figure 6. Borehole geometry data deduced from BHTV and FMS data. A. Comparison of orientation of elongation from BHTV and FMS borehole geometry data from Hole 829A. B. Comparison of orientation of elongation from BHTV and FMS borehole geometry data from Hole 831B. Arrows represent bit size. 
A
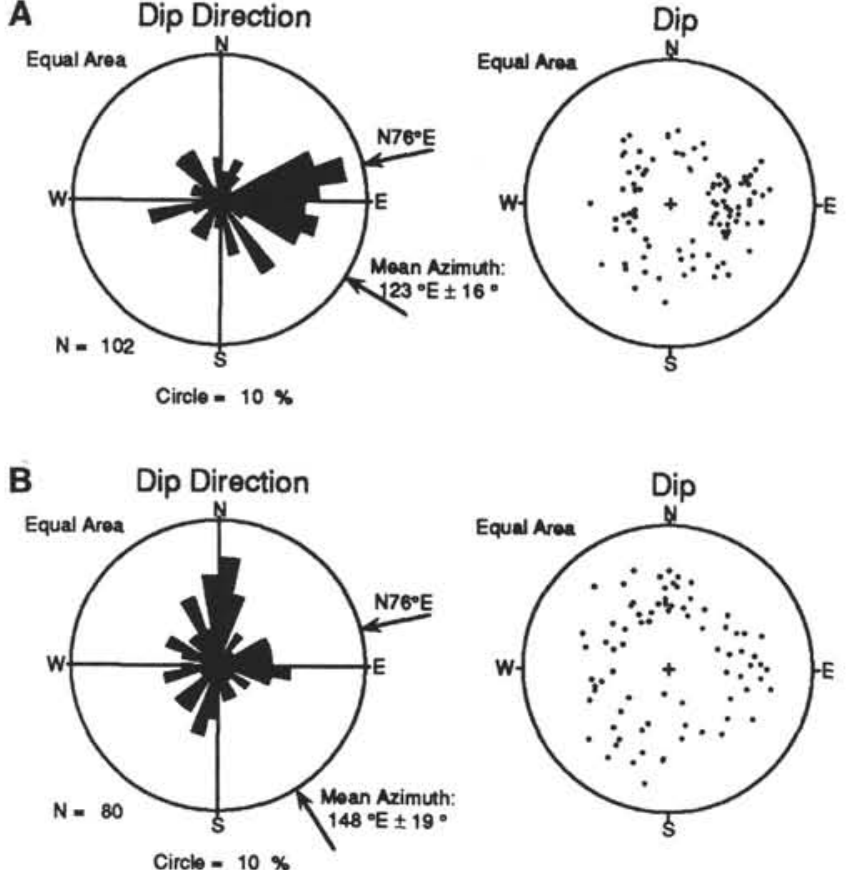

Figure 7. Rose and pole diagrams from structures detected with the borehole televiewer. A. Hole 829A. B. Hole 831B. Arrows mark orientation of plate convergence $\left(76^{\circ}\right)$ and orientation of borehole elongation derived from BHTV data.

In-situ pore pressure measurements in accretionary wedges are rare and have shown that pore pressure can reach near-lithostatic values just above the décollement (Wuthrich et al., 1990). In-situ pore pressure measurements from Leg 134 are not available. It was calculated, however, that lithostatic pore pressure would exceed hydrostatic pore pressure only by $17 \%$ for depths reached by Hole $829 \mathrm{~A}$ in the accretionary wedge. Therefore, hydrostatic pore pressure was assumed for the calculations. This gives a lower limit for the calculation of Equation 5.

If these assumptions apply, the Coulomb criterion for optimally oriented faults suggests (Jaeger and Cook, 1979):

$$
\left(\mathrm{S}_{1}-\mathrm{P}_{\mathrm{p}}\right) /\left(\mathrm{S}_{3}-\mathrm{P}_{\mathrm{p}}\right)=\left(\left[1+\mu^{2}\right]^{1 / 2}+\mu\right)^{2},
$$

with $S_{1}$ the maximum principal stress, $S_{3}$ the minimum principal stress, and $\mathrm{P}_{\mathrm{p}}$ the formation pore pressure. With these assumptions, the magnitude of stress as a function of depth can be calculated, if the stress indicators (normal faulting, $\mathrm{S}_{1}=\mathrm{S}_{\mathrm{v}}$; thrust faulting, $\mathrm{S}_{1}=\mathrm{S}_{\mathrm{H}}$; strike slip faulting, $S_{2}=S_{v}$ ) are obtained (e.g., from earthquake focal mechanism solutions).

In addition, the following information is available to estimate the stress regimes and stress magnitudes in the wells:

1. Earthquakes close to the Australia/Pacific Plate boundary show normal fault regimes (Fig. 9B) and, therefore, may be associated with flexural stresses in the subducting slab.

2. Earthquakes east of the Australia/Pacific Plate boundary show prevailing compressive stress regimes (Figs. 9A and 9B) with P-axes oriented almost normal to the plate boundary and parallel to the relative motion of the Australia-Pacific plates (Isacks et al., 1981).

3. A compressive stress regime can be expected in the accretionary wedge due to observed thrust faulting (Collot, Greene, Stokking, et al., 1992).

4. The overall predominant horizontal stress is compressive with the maximum horizontal stress direction showing east-northeastwest-southwest.
A

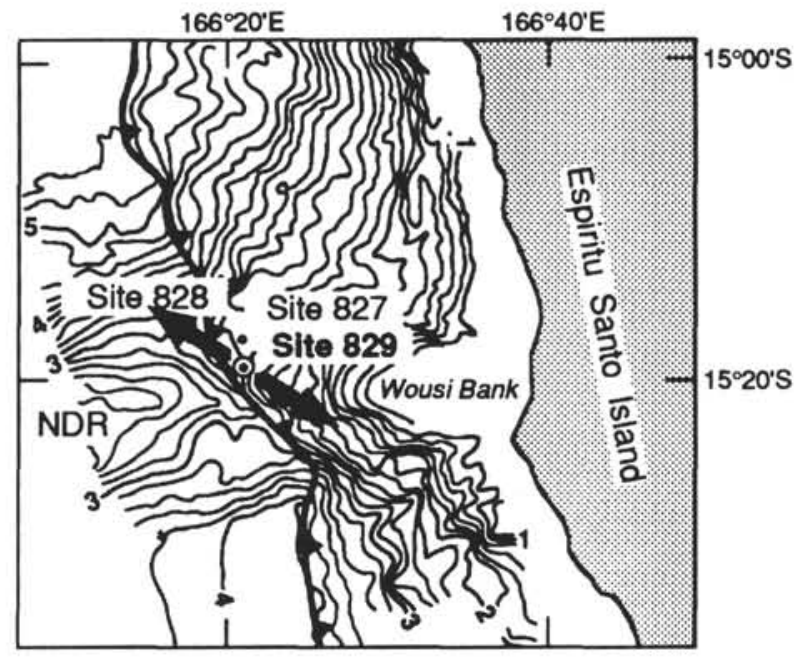

B

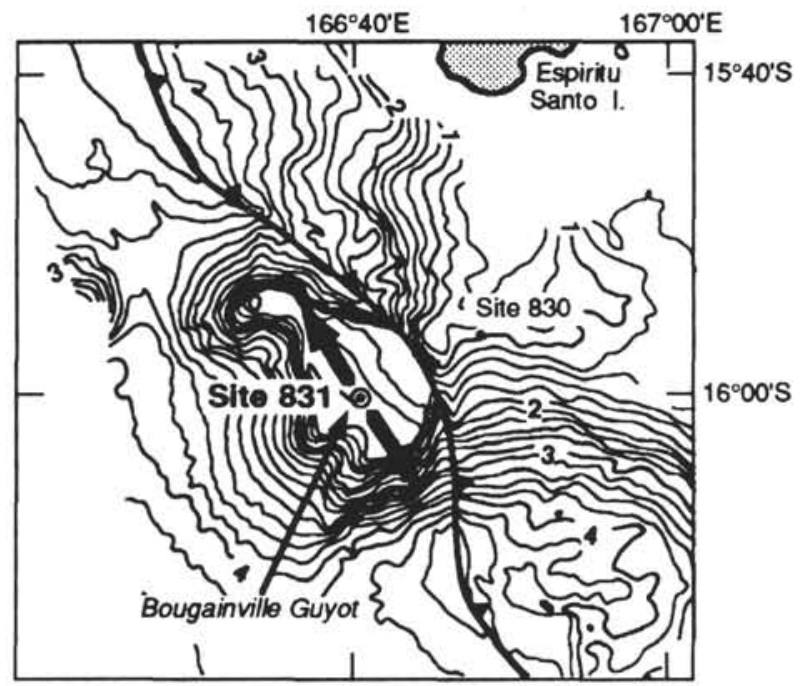

Figure 8. Detailed bathymetric maps of the collision zone between the d'Entrecasteaux Zone and the Central New Hebrides Island Arc. For overview see Figure 1. Bathymetric contours are in kilometers. A. Orientation of borehole elongation, indicated by arrows, as deduced from BHTV data from Hole 829A. NDR = North d'Entrecasteaux Ridge. B. Orientation of borehole elongation, indicated by arrows, as deduced from BHTV data from Hole 831B.

Thus for the computation of reasonable lower bounds for the stress magnitudes, a reverse fault (RF) stress regime was assumed for Hole $829 \mathrm{~A}$ and a normal fault (NF) as well as a reverse fault (RF) stress regime was assumed for Hole 831B. A strike slip (SS) component was incorporated due to the oblique component of motion of the DEZ in relation to the trench and observed lineaments with strike slip displacements (Collot et al., 1992).

The following depth and density values were used from logging data (Collot, Greene, Stokking, et al., 1992) to calculate possible magnitude ranges of the vertical and horizontal stresses (Table 1).

Figures $10 \mathrm{~A}$ and $10 \mathrm{~B}$ show the variation of circumferential stress for varying borehole shapes, a frictional strength of $\mu=0.8$, and given stress regimes at different depths in Holes 829A and 831B. The figures do not include information about rock strength from laboratory measurements, as there is a wide range of rock strength for sedimentary rocks. It is also obvious that based on these models, stresses in the same crustal level are higher in Hole 829A than those in Hole 831B. For example, there is a $20 \mathrm{MPa}$ difference in $\mathrm{S}_{\mathrm{H} \max }$ at $600 \mathrm{mbsf}$. Based on these assumptions, the figures illustrate that assuming a reverse fault/ strike slip (RF/SS) regime, breakouts would occur unless the rock 


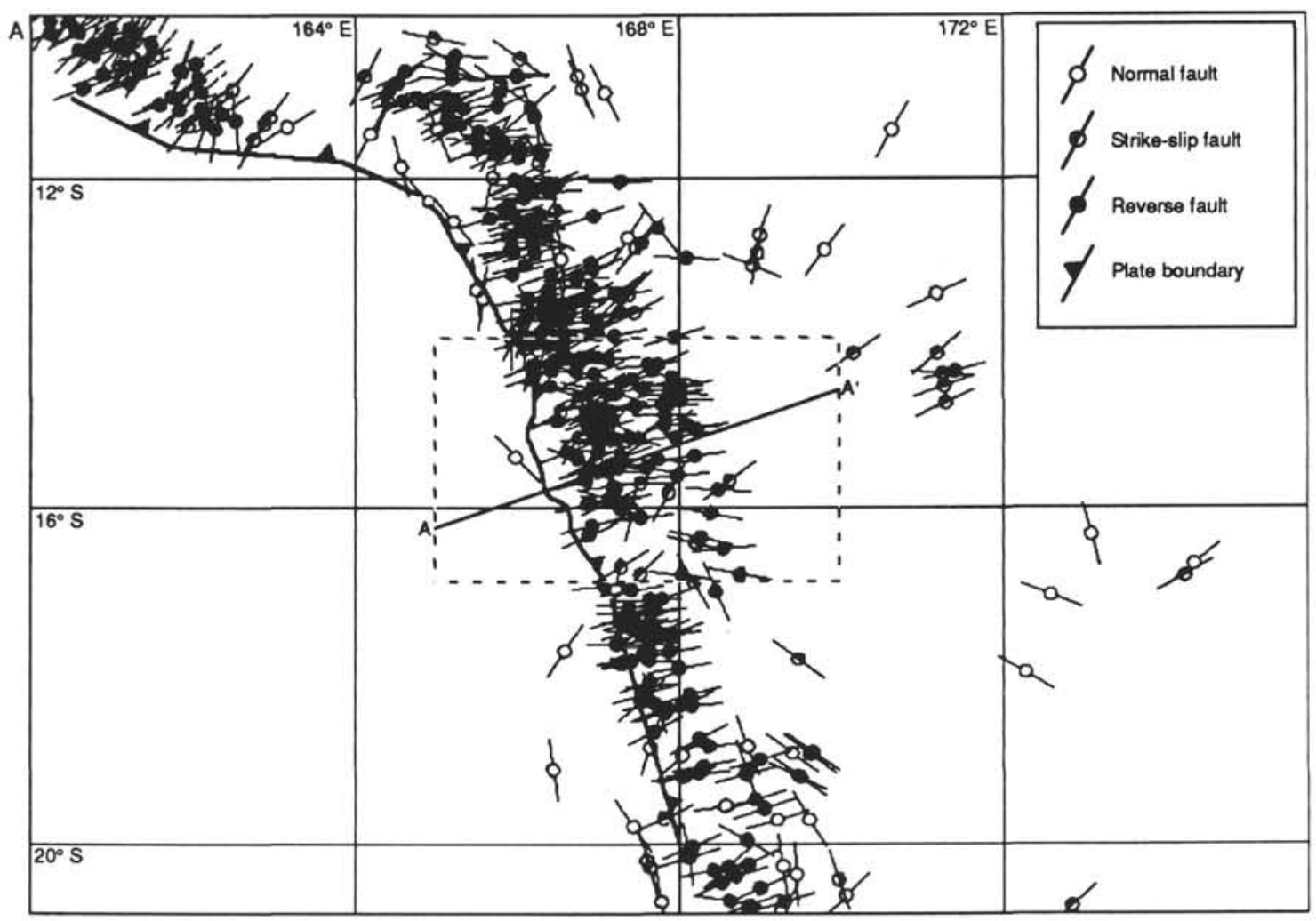

B

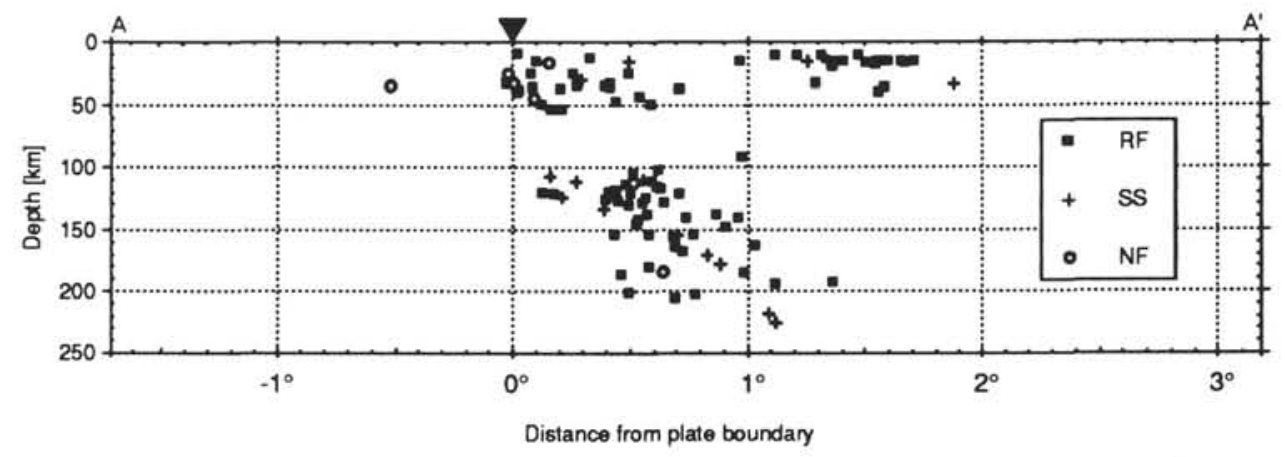

Figure 9. Earthquake distribution according to centroid moment tensor solutions in the Central New Hebrides subduction zone. A. Overview on the seismicity in the Central New Hebrides subduction zone. Location of the earthquakes are marked with circles. Bars indicate the orientation of maximum horizontal stress derived from centroid moment tensor solutions. Different symbols (see legend) represent different types of earthquake focal mechanisms. Dashed line encloses area displayed in Figure 9B. Line A-A' marks cross section of Figure 9B. B. Earthquake depth distribution of the enclosed area in Figure 10A projected on a cross section parallel to line $\mathrm{A}-\mathrm{A}^{\prime}$. Horizontal distance is relative to the plate boundary, which is marked by a triangle. Focal mechanisms are shown with different symbols $(\mathrm{RF}=$ reverse faulting regime, $\mathrm{SS}=$ strike-slip faulting regime, $\mathrm{NF}=$ normal faulting regime $)$.

strength exceeds $150 \mathrm{MPa}$ at 3335 meters below sea level (mbsl, 430 mbsf) or $200 \mathrm{MPa}$ at $3455 \mathrm{mbsl}$ (550 mbsf) in Hole 829A (Fig. 10A), or $250 \mathrm{MPa}$ in Hole $831 \mathrm{~B}$ (Fig. 10B) at $1866 \mathrm{mbsl}$ ( $800 \mathrm{mbsf}$ ).

However, neither breakouts nor vertical fractures were observed in the data, which leads to the following possible conclusions:

1. The magnitudes of the contemporary stresses at depth are not as high as the models predict, and/or,

2 . the rock strength is higher than expected, and/or,

3 . the pore pressure is higher or $\mu$ is lower leading to "weaker" rocks, and/or
4. stress relief by decoupling along faults or by inelastic processes takes place.

Figure $10 \mathrm{~A}$ illustrates that for the assumed conditions tensile stresses are predicted for circular boreholes in a RF/SS regime. In case, that rock strength and frictional strength would be known more precisely from laboratory measurements, upper limits on the absolute magnitude for $\mathrm{S}_{\mathrm{H} \max }$ could be calculated. Whereas no direct measurements were available to determine the parameters described under (2) and (3), thrust faults (4) have been observed in the cores. In particular, Hole $829 \mathrm{~A}$, drilled into the accretionary wedge, shows characteris- 
A

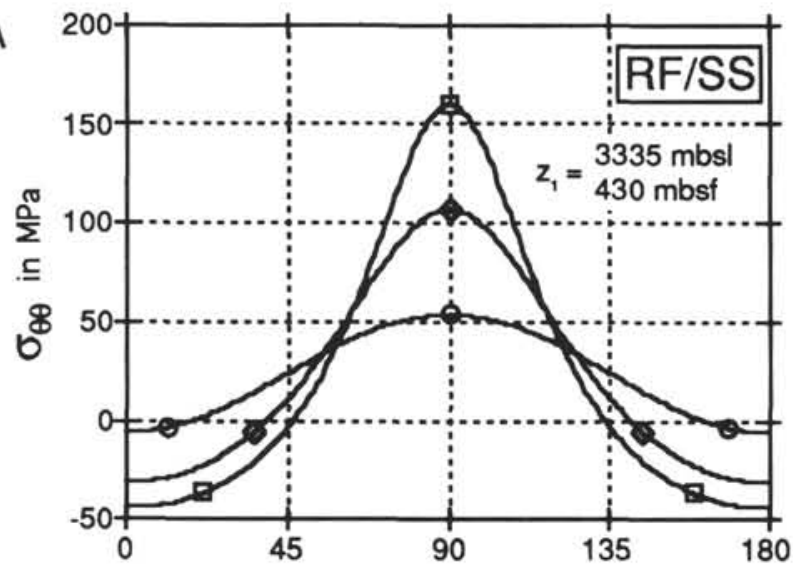

B

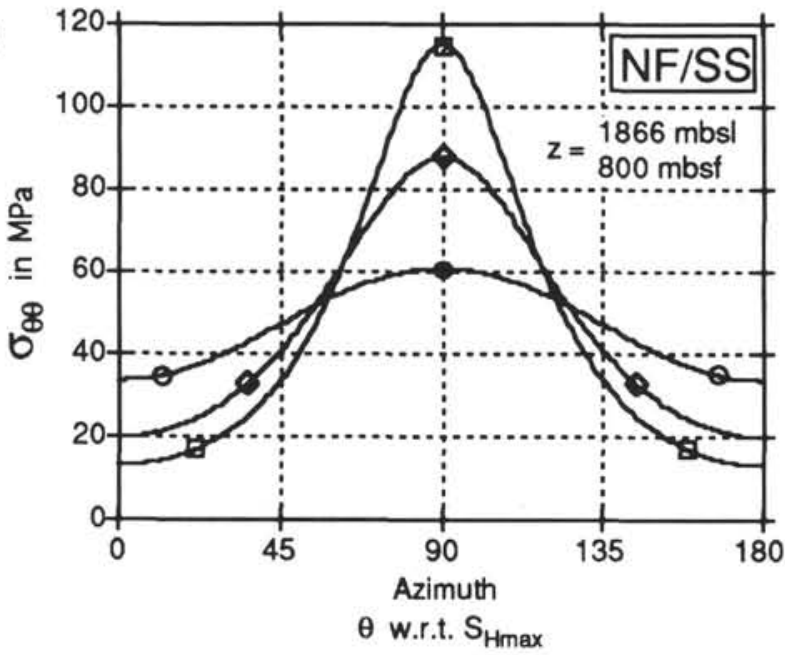

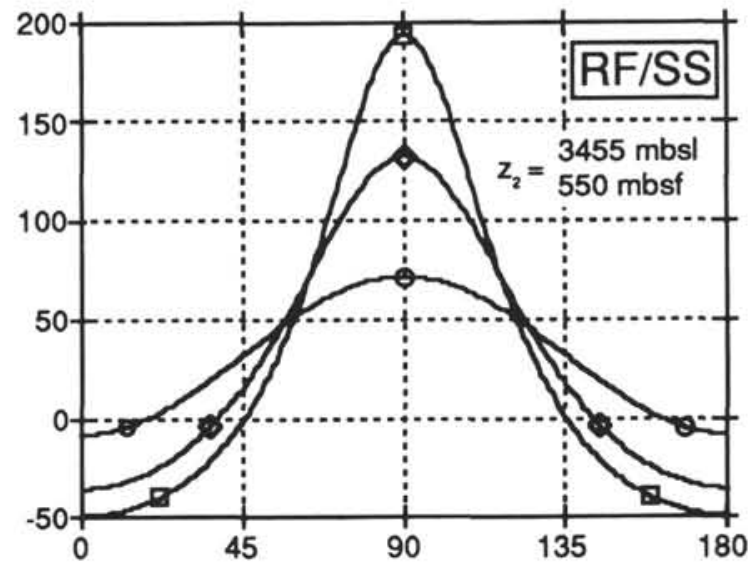

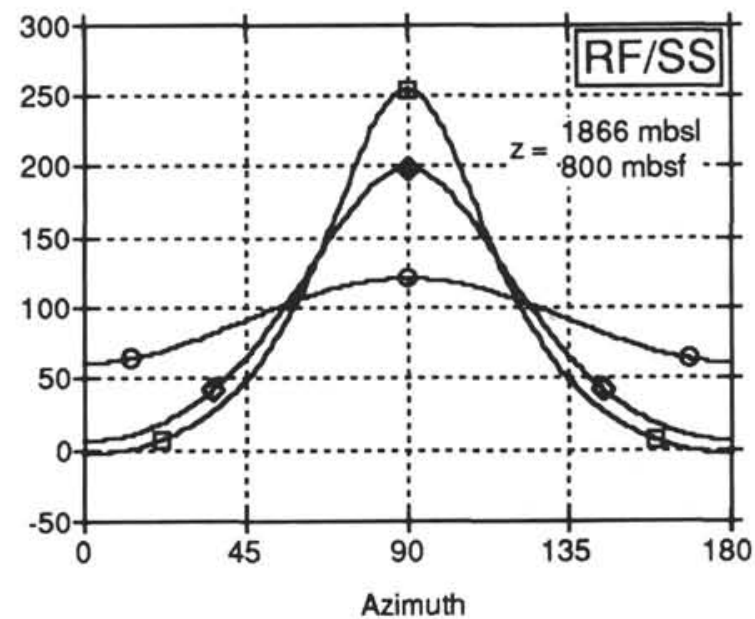

$\theta$ w.r.t. $S_{H \max }$

$$
\begin{array}{|l|}
\hline- \text { Circ. } \\
-\multimap \text { Ell. }(m=-0.2) \\
\square \text { Ell. }(m=-0.3)
\end{array}
$$

Figure 10. Circumferential stresses with respect to the maximum horizontal stress $\mathrm{S}_{\mathrm{Hmax}}$ in circular (circ.) and elliptical (ell.) boreholes under reverse-fault/strike-slip (RF/SS) and normal-fault/strike-slip (NF/SS) regimes. Different axis ratios (m), as described in Equation 1, and a coefficient of friction $\mu=0.8$, were used for the calculations. Breakouts should occur when the circumferential stress exceeds the compressive strength of the rock. Tensile fractures should develop when the tensile strength of the rock is exceeded. A. Circumferential stresses in Hole $829 \mathrm{~A}$ under a reverse-fault/strike-slip regime at the maximum depth reached by the borehole televiewer $\left(\mathrm{z}_{1}\right)$ and at the maximum depth reached by drilling $\left(\mathrm{z}_{2}\right)$. B. Circumferential stresses in Hole 831B under reverse-fault/strike-slip and normal-fault/strike-slip regimes; mbsl = meters below sea level.

tics of thrust faulting (Meschede and Pelletier, this volume; Collot, Greene, Stokking, et al., 1992). As no borehole breakouts or tensile fractures were observed, these thrust faults could have acted as zones of stress relief and, therefore, stresses never reached magnitudes high enough to create breakouts or tensile fractures.

However, the observed uniform azimuthal elongations of the boreholes remain to be explained. In general, they may be caused by the present day stress field or drilling effects (e.g., drillpipe wear, key seats).

Drilling effects cannot be rejected totally as a reason for the observations. Nevertheless, we propose that the above effects are caused by the stress field rather than drilling effects for the following reasons and possible interactions:
Table 1. Depth intervals and densities from logging data used for the calculation of the stress regimes and magnitudes.

\begin{tabular}{rr}
\hline Depth $(\mathrm{m})$ & $\rho\left(\mathrm{kg} / \mathrm{m}^{3}\right)$ \\
\hline Hole 829A & \\
$0-2905$ & 1030 \\
$2905-3075$ & 1900 \\
$3075-3275$ & 2200 \\
$3275-3515$ & 2300 \\
Hole 831B & \\
$0-1066$ & 1030 \\
$1066-1416$ & 2200 \\
$1416-1726$ & 2300 \\
$1726-1866$ & 2400 \\
\end{tabular}


1. The analysis of the dip direction of intersecting fractures observed in BHTV data from Hole 829A shows that the main dip direction of the structures $\left(80^{\circ}\right.$, Fig. $\left.7 \mathrm{~A}\right)$ correlates with the direction of plate convergence $\left(76^{\circ}\right.$; Isacks, et al., 1981). This agrees with core observations and analysis of structural features from FMS data (Collot, Greene, Stokking, et al., 1992). However, orientation of elongation is $123^{\circ}, 47^{\circ}$ east of the direction of plate convergence. In contrast hereto, no preferred dip orientation of structures was observed in Hole 831B (Fig. $8 \mathrm{~B})$. Therefore, fracture dips, which might have caused the wellbore to deviate up- or down-dip causing up- or down-dip borehole elongations, cannot be responsible for the orientation of the observed elongations.

2. Key seats as described by Plumb and Hickman (1985) were not observed in the FMS dipmeter data.

3. The deviation of both boreholes is less than $5^{\circ}$.

If the uniform azimuthal elongations as observed in the BHTV data are caused by the present day stress field rather than by drilling processes, elongations should trend into the direction of the minimum horizontal stress $\mathrm{S}_{\mathrm{hmin}}$. According to the presented stress model this would imply that the orientation of the maximum horizontal stress $\mathrm{S}_{\mathrm{Hmax}}$ for Hole $829 \mathrm{~A}$ would be $33^{\circ} \mathrm{E}$ and for Hole $831 \mathrm{~B} 58^{\circ} \mathrm{E}$.

These orientations agree with topographic and structural data as well as with the trend of the Australia/Pacific Plate boundary. Figures $8 \mathrm{~A}$ and $\mathrm{B}$ show detailed bathymetric maps of the drill sites for Holes $829 \mathrm{~A}$ and $831 \mathrm{~B}$, and the course of the plate boundary as deduced from bathymetry. The observed bathymetry reflects the combined collisionsubduction process, a product of the oblique motion of the DEZ relative to the trench $\left(76^{\circ} \pm 11^{\circ}, 2.5 \mathrm{~cm} / \mathrm{y}\right.$, Isacks et al., 1981) at a convergence rate of $9 \mathrm{~cm} / \mathrm{y}$ that resulted in characteristic structures along and across the collision zone (Collot and Fisher, 1992; Collot et al., 1992). The $123^{\circ}$ directed orientation of elongation of Hole 829A, which is situated at the toe of the Wousi Bank, is parallel to the slope of the Wousi Bank indicating that topographic effects might have influenced this orientation (Fig. 8A). The orientation of the elongation of Hole 831B $\left(148^{\circ}\right)$, however, is nearly parallel to the long axis of the Bougainville Guyot and the NNW-SSE striking plate boundary (Fig. 8B).

\section{Hole 829A}

At the northern part of the DEZ, the collision of the NDR and the New Hebrides Island Arc did not produce such a strong concave indentation of the arc as the Bougainville Guyot does in the south. However, the NDR deformed and/or formed the Wousi Bank, a WNWESE trending protrusion. Hole $829 \mathrm{~A}$ is situated on a small flat platform at the toe of the Wousi Bank. The elongation of the borehole axis at this site strikes $123^{\circ}$. This parallels the slope of the Wousi Bank and observed lineaments, which trend $120^{\circ}-140^{\circ}$ (Collot and Fisher, 1992 ; Collot et al., 1992). Despite the close vicinity of Hole 829A to the plate boundary, which is associated with a great number of earthquakes, stresses are too low to create direct stress indicators such as borehole breakouts. This suggests, that processes such as decoupling along thrust faults reduce the acting stresses in the accretionary wedge.

\section{Hole 831B}

At the southern part of the DEZ, the Bougainville Guyot collides with the southern submarine extension of Espiritu Santo Island. Here the collision zone is characterized by a concave eastward deformation of the trench as the Bougainville Guyot indents the arc. Due to the indention, the Bougainville Guyot should experience compressive stresses parallel to the direction of plate convergence. Hole $831 \mathrm{~B}$ is situated at the center of the Bougainville Guyot and the azimuth of elongation at this site $\left(148^{\circ}\right)$ is parallel to the long axis of the Bougainville Guyot and the deformed trench. The non-existence of breakouts indicates that stresses are not high enough to create breakouts, or that stress relaxation takes place along faults.
The correlation of the stress orientation (deduced from borehole elongations) with local topographic and structural features at Hole $829 \mathrm{~A}$ and the direction of plate convergence at Hole 831B is striking. This correlation suggests that despite the fact that no true stress indicator (borehole breakout, tensile fracture) exists, the observed elongations are due to the present day stress field rather than drilling effects. At Holes $829 \mathrm{~A}$ and $831 \mathrm{~B}$ the orientation of the maximum horizontal stress is rotated by $43^{\circ}$ (Hole $\left.829 \mathrm{~A}\right)$ and $18^{\circ}$ (Hole $831 \mathrm{~B}$ ) northwards to the plate convergence direction of $76^{\circ}$ (Isacks et al., 1981). This indicates that local effects, such as topography, are superimposing and deflecting the regional stress field. Observations of borehole elongations in a similar environment are reported from Pezard et al. (1992). They derived those elongations according to the criteria of Plumb and Hickman (1985) from FMS dipmeter data and called them breakouts. If dipmeter data fulfil those criteria, BHTV data cannot be proved because no BHTV data from the boreholes studied by Pezard et al. (1992) are available.

\section{CONCLUSIONS}

The detailed analysis of BHTV data from ODP Holes 829A and $831 \mathrm{~B}$ drilled into the collision zone of the DEZ and the New Hebrides Island Arc did not show any direct in-situ stress indicators. The absence of stress indicators led to the conclusion that additional processes, such as decoupling on fault planes, reduce the applied stresses. The orientation of borehole elongation of $123^{\circ}$ in Hole $829 \mathrm{~A}$ and its strong correlation with topography and linear structures suggests that local effects deflect the regional stress field of the present day collision zone. In contrast, orientation of borehole elongations in Hole $831 \mathrm{~B}\left(148^{\circ} \mathrm{E}\right)$ correlates well with the course of the plate boundary and the direction of plate convergence.

\section{ACKNOWLEDGMENTS}

This work was supported by the Deutsche Forschungsgemeinschaft (DFG, grant Fu 55/32-1,2). The DFG also enabled data recording by the kind provision of a digital borehole televiewer. We also like to thank Mrs. B. Müller and M. Brudy for many thoughtful discussions. This manuscript benefited greatly from the helpful comments of D. Moos and R. Morin. We also thank M.D. Zoback, who provided the BHTV analysis program to the Geophysical Institute at the University of Karlsruhe, and C.A. Barton of Stanford University for her efforts on writing and improving the BHTV analysis program.

\section{REFERENCES}

Barton, C.A., Tessler, L., and Zoback, M.D., 1991. Interactive analysis of borehole televiewer data. In Palaz, I., and Sengupta, S. (Eds.), Automated Pattern Analysis in Petroleum Exploration: New York (Springer Verlag), 217-242.

Bell, J.S., and Gough, D.I., 1979. Northeast-southwest compressive stress in Alberta: evidence from oil wells. Earth Planet. Sci. Lett., 45:475-482.

Blümling, P., 1986. In-situ Spannungsmessungen in Tiefbohrungen mit Hilfe von Bohrlochrandausbrüchen und die Spannungsverteilung in der Kruste Mitteleuropas und Australiens [Ph.D. dissert.]. Univ. Karlsruhe.

Blümling, P., and Schneider, T., 1986. Bohrlochrandausbrüche in Tiefbohrungen und ihre Beziehung zum rezenten Spannungsfeld. Berichtsband für die Jahre 1984-1986 des Sonderforschungsbereichs 108, Univ. Karlsruhe.

Bott, M.H.P., Waghorn, G.D., and Whittaker, A., 1989. Plate boundary forces at subduction zones and trench-arc compression. Tectonophysics, 170:1-15.

Byerlee, J.D., 1978. Friction of rocks. Pure Appl. Geophys., 116:615-626.

Castillo, D.A., and O'Neill, B., 1992. Constraints on the state of stress in old oceanic crust of the Indo-Australian Plate, northwest of Australia. In

\footnotetext{
- Abbreviations for names of organizations and publications in ODP reference lists follow the style given in Chemical Abstracts Service Source Index (published by American Chemical Society).
} 
Gradstein, F.M., Ludden, J.N., et al., Proc. ODP, Sci. Results, 123: College Station, TX (Ocean Drilling Program), 503-513.

Chapple, W.M., 1979. Mechanics of thin-skinned fold-and-thrust belts. Geol. Soc. Am. Bull., 89:1189-1198.

Cloetingh, S., and Wortel, R., 1986. Stress in the Indo-Australian plate. Tectonophysics, 132:49-67.

Collot, J.-Y., and Fisher, M.A., 1992. The d'Entrecasteaux Zone-New Hebrides Island Arc collision zone: an overview. In Collot, J.-Y., Greene, H.G., Stokking, L.B., et al., Proc. ODP, Init. Repts., 134: College Station, TX (Ocean Drilling Program), 19-31.

Collot, J.-Y., Greene, H.G., Stokking, L.B., et al., 1992. Proc. ODP, Init. Repts., 134: College Station, TX (Ocean Drilling Program).

Collot, J.-Y, Lallemand, S., Pelletier, B., Eissen, J.-P., Glaçon, G., Fisher, M.A., Greene, H.G., Boulin, J., Daniel, J., and Monzier, M., 1992. Geology of the d'Entrecasteaux-New Hebrides island arc collision: results from a deep-sea submersible survey. Tectonophysics, 212:213-241.

Dziewonski, A.M., Ekström, G., Franzen, J.E., and Woodhouse, J.H., 1987a. Centroid-moment tensor solutions for January-March 1986. Phys. Earth Planet. Inter., 45:1-10.

, 1987b. Centroid-moment tensor solutions for April-June 1986 Phys, Earth Planet. Inter, 45:229-239.

, 1987c. Centroid-moment tensor solutions for July-September 1986. Phys. Earth Planet. Inter., 46:303-315.

1987d. Global seismicity of 1979: centroid-moment tensor solutions for 524 earthquakes. Phys. Earth Planet. Inter., 48:18-46.

1987e. Global seismicity of 1978: centroid-moment tensor solutions for 512 earthquakes. Phys. Earth Planet. Inter, 50:316-342.

, 1987f. Global seismicity of 1977: centroid-moment tensor solutions for 471 earthquakes. Phys. Earth Planet. Inter., 50:11-36.

, 1988a. Global seismicity of 1981: centroid-moment tensor solutions for 542 earthquakes. Phys. Earth Planet. Inter., 50:155-182.

, 1988b. Global seismicity of 1980: centroid-moment tensor solutions for 515 earthquakes. Phys. Earth Planet. Inter., 50:127-154.

_ 1988c. Global seismicity of 1982 and 1983: additional centroidmoment tensor solutions for 553 earthquakes. Phys. Earth Planet. Inter. $53: 17-45$

Dziewonski, A.M., Ekström, G., Woodhouse, J.H., and Zwart, G., 1987. Centroid-moment tensor solutions for October-December 1986. Phys. Earth Planet. Inter., 48:5-17.

, 1988a. Centroid-moment tensor solutions for January-March 1987. Phys. Earth Planet. Inter., 50:116-126.

1988b. Centroid-moment tensor solutions for April-June 1987. Phys, Earth Planet. Inter, 50:215-225.

, 1988c. Centroid-moment tensor solutions for July-September 1987. Phys. Earth Planet. Inter., 53:1-11.

, 1989a. Centroid-moment tensor solutions for October-December 1987. Phys. Earth Planet. Inter., 54:10-21.

1989b. Centroid-moment tensor solutions for January-March 1988. Phys. Earth Planet. Inter, 54:22-32.

1989c. Centroid-moment tensor solutions for April-June 1988. Phys. Earth Planet. Inter., 54:199-209.

1989d. Centroid-moment tensor solutions for July-September 1988. Phys. Earth Planet. Inter., 56:165-180.

1989e. Centroid-moment tensor solutions for October-December 1988. Phys. Earth Planet. Inter, 57:179-191.

- 1990. Centroid-moment tensor solutions for January-March 1989. Phys. Earth Planet. Inter, 54:233-242.

Dziewonski, A.M., Franzen, J.E., and Woodhouse, J.H., 1983a. Centroid-moment tensor solutions for January-March 1983. Phys. Earth Planet. Inter, 33:71-75.

, 1983b. Centroid-moment tensor solutions for April-June 1983. Phys. Earth Planet. Inter, 33:243-249.

1984a. Centroid-moment tensor solutions for July-September 1983. Phys. Earth Planet. Inter., 34:1-8.

1984b. Centroid-moment tensor solutions for October-December 1983. Phys. Earth Planet. Inter., 34:129-136.

, 1984c. Centroid-moment tensor solutions for January-March 1984. Phys. Earth Planet. Inter, 34:209-219.

1984d. Centroid-moment tensor solutions for April-June 1984. Phys. Earth Planet. Inter., 37:87-96.

, 1984e. Centroid-moment tensor solutions for July-September 1984. Phys. Earth Planet. Inter, 38:203-213. 1984f. Centroid-moment tensor solutions for October-December 1984. Phys. Earth Planet. Inter., 39:147-156.

, 1985. Centroid-moment tensor solutions for January-March 1985. Phys. Earth Planet. Inter, 40:249-258.

1986a. Centroid-moment tensor solutions for April-June 1985. Phys. Earth Planet. Inter, 41:215-224.

1986b. Centroid-moment tensor solutions for July-September 1985. Phys. Earth Planet. Inter., 42:205-214.

1986c. Centroid-moment tensor solutions for October-December 1985. Phys. Earth Planet. Inter, 43:185-195.

Dziewonski, A.M., Friedmann, A., Giardini, D., and Woodhouse, J.H., 1983. Global seismicity of 1982: centroid-moment tensor solutions for 308 earthquakes. Phys. Earth Planet. Inter, 33:76-90.

Ekstrom, M.P., Dahan, C., Chen, M.-Y., Lloyd, P., and Rossi, D.J., 1987. Formation imaging with microelectrical scanning arrays. Log Analyst, 28:294-306.

Forsyth, D., and Uyeda, S., 1975. On the relative importance of the driving forces of plate motion. Geophys. J. R. Astron. Soc., 43:163-200.

Isacks, B.L., Cardwell, R.K., Chatelain, J.L., Barazangi, M., Marthelot, J.-M., Chinn, D., and Louat, R., 1981. Seismicity and tectonics of the central New Hebrides island arc. In Simpson, D.W., and Richards, P.G. (Eds.), Earthquake Prediction: An International Review. Am. Geophys. Union, Maurice Ewing Ser., 4:93-116.

Jaeger, J.C., and Cook, N.G.W., 1979. Fundamentals of Rock Mechanics (3rd ed.): New York (Chapman and Hall).

Kirsch, G., 1898. Die Theorie der Elastizität und die Bedürfnisse der Festigkeitslehre. VDI Z., 42:770-807.

Mardia, K.V., 1972. Probability and Mathematical Statistics: London (Academic Press)

Mastin, L., 1988. Effect of borehole deviation on breakout orientations. $J$. Geophys. Res., 93:9187-9195.

Mastin, L.G., Heinemann, B., Krammer, A., Fuchs, K., and Zoback, M.D., 1991. Stress orientation in the KTB pilot hole determined from wellbore breakouts. Sci. Drill., 2:1-12.

Menger, S., 1991. Experimentelle und numerische Untersuchungen zum Problem der Dezentrierung beim Akustischen Bohrloch Televiewer. Ber. Inst. Geophys. Ruhr-Univ. Bochum, Reihe A, 32.

Moos, D., and Zoback, M.D., 1990. Utilization of observations of well bore failure to constrain the orientation and magnitude of crustal stresses: application to continental, Deep Sea Drilling Project, and Ocean Drilling Program boreholes. J. Geophys. Res., 95:9305-9325.

Morin, R.H., Anderson, R.N., and Barton, C.A., 1989. Analysis and interpretation of the borehole televiewer log: information on the state of stress and the lithostratigraphy at Hole 504B. In Becker, K., Sakai, H., et al., Proc. ODP, Sci. Results, 111: College Station, TX (Ocean Drilling Program), 109-118.

Morin, R.H., Newmark, R.L., Barton, C.A., and Anderson, R.N., 1990. State of lithospheric stress and borehole stability at Deep Sea Drilling Project Site 504B, eastern Equatorial Pacific. J. Geophys. Res., 95:9293-9303.

Muskhelishvili, N.I., 1953. Some Basic Problems of the Mathematical Theory of Elasticity (4th ed.): Groningen (Noordhoff). Translated by J.R.M. Radok.

Newmark, R.L., Zoback, M.D., and Anderson, R.N., 1984. Orientation of in situ stresses in the oceanic crust. Nature, 311:424-428.

Pezard, P.A., 1987. New applications of continuous electrical resistivity measurements in ODP drillholes. Eos, 68:268.

Pezard, P.A., Hiscott, R.N., Lovell, M.A., Collela, A., and Malinverno, A., 1992. Evolution of the Izu-Bonin intraoceanic forearc basin, western Pacific, from cores and FMS images. In Hurst, A., Griffiths, C.M., and Worthington, P.F. (Eds.), Geological Applications of Wireline Logs II. Geol. Soc. Spec. Publ. London, 65:43-69.

Plumb, R.A., and Hickman, S.H., 1985. Stress-induced borehole elongation: a comparison between the four-arm dipmeter and the borehole televiewer in the Auburn geothermal well. J. Geophys. Res., 90:5513-5521.

Ritchie, R.H., and Sakakura, A.Y., 1956. Asymptotic expansions of solutions of the heat conduction equation in internally bounded cylindrical geometry. J. Appl. Phys., 27:1453-1459.

Timoshenko, S., 1959. Theory of Elasticity: New York (McGraw Hill).

Wuthrich, D.R., Screaton, E.J., and Dreiss, S.J., 1990. Fluid flow within the Barbados Ridge complex, Part II: permeability estimates and numerical simulations of flow velocities and pore pressures. In Moore, J.C., Mascle, A., et al., Proc. ODP, Sci. Results, 110: College Station, TX (Ocean Drilling Program), 331-341. 
Zemanek, J., Caldwell, R.L., Glenn, E.E., Jr., and Holcomb, S.V., 1969. The borehole televiewer-a new logging concept for fracture location and other types of borehole inspection. J. Pet. Technol., 21:762-774.

Zemanek, J., Glenn, E.E., Norton, L.J., and Caldwell, R.L., 1970. Formation evaluation by inspection with the borehole televiewer. Geophysics, 35:254-269.

Zoback, M.D., Moos, D., Mastin, L., and Anderson, R.N., 1985. Well bore breakouts and in situ stress. J. Geophys. Res, 90:5523-5530.

Zoback, M.L., Zoback, M.D., Adams, J., Assumpção, M., Bell, S., Bergman, E.A., Blümling, P., Brereton, N.R., Denham, D., Ding, J., Fuchs, K., Gay,
N., Gregersen, S., Gupta, H.K., Gvishiani, A., Jacob, K., Klein, R., Knoll, P., Magee, M., Mercier, J.L., Müller, B.C., Paquin, C., Rajendran, K. Stephansson, O., Suarez, G., Suter, M., Udias, A., Xu, Z.H., and Zhizhin,

M., 1989. Global patterns of tectonic stress. Nature, 341:291-298.

Date of initial receipt: 11 May 1992

Date of acceptance: 16 August 1993

Ms 134SR-034 